\title{
EU Water Framework Directive and Stockholm Convention
}

\author{
Can we reach the targets for priority substances and persistent organic pollutants?
}

\author{
Maria Fuerhacker
}

Received: 3 December 2008 / Accepted: 14 December 2008/Published online: 1 April 2009

(C) Springer-Verlag 2009

\begin{abstract}
Background, aim and scope Water is a renewable resource and acceptable quality is important for human health, ecological and economic reasons, but human activity can cause great damage to the natural aquatic environment. Managing the water cycle in a sustainable way is the key to protect natural resources and human health. On a global level, the microbiological contamination of water sources is a major problem in connection with poverty and the United Nations Millennium Development Declaration is an important initiative to handle this problem. In terms of environmental health, persistent organic pollutants (POPs) circulate globally; as they travel long distances, they are found in remote areas far from their original source of application and can cause damage wherever they move to. On a global scale, United Nations Environmental Programme (UNEP) issued the Stockholm Convention to reduce POPs; in the European Union (EU), one intention of the Water Framework Directive (WFD) is to reach the good chemical status of waters; beside these regulations, there are other directives in support of these goals. The aim of this paper is to discuss whether the Stockholm Convention and the WFD allows meeting the targets of protection of human and environmental health, which are established in the different directives and how could we approach the targets.
\end{abstract}

Responsible editor: Walter Giger

ESPR Special Issue - ESTROM

M. Fuerhacker $(\bowtie)$

Institute of Sanitary Engineering and Water Pollution Control,

University of Natural Resources and Applied Life Sciences Vienna,

Muthgasse 18,

1190 Vienna, Austria

e-mail: maria.fuerhacker@boku.ac.at
Materials and methods The aims and scopes of different directives are compiled and compared with the actual quality of water, different approaches of standard settings are compared and potential treatment options are discussed. Results Under the Stockholm Convention on POPs, which came into force in May 2004, governments are required to develop a National Implementation Plan (NIP) setting out how they will address their obligations under the convention and how they will take measures to eliminate or reduce the release of POPs into the environment by the use of best available techniques (BAT) and application of best environmental practices (BEP). On a European level, the WFD has been in place as the main European legislation to protect our water resources and the water environment of Europe since 2000. It requires managing river basins so that the quality and quantity of water does not affect the ecological services of any specific water body. Nevertheless, the goals of other directives as for drinking water, bathing water and urban wastewater treatment are not yet harmonised mainly concerning microbiological, priority substances and priority hazardous substances (PS/PHS) contamination. Following the detection of substances, a risk assessment with sound effect data needs to be performed also for regulatory decisions and priorisation of measures to remove emerging contaminants. Beside personal care products and industrial contaminants, faecal pollution of recreational waters is one of the major hazards facing users, although microbial contamination from other sources as well as chemical and physical aspects also affects the suitability of water for recreation. As in arid and semiarid areas, wastewater is considered for irrigation with regulatory needs of hygienic and chemical parameters - health-based targets - to avoid the contamination of crops and food. In surface waters, currently, the relationships between physical and chemical properties and the biological state of surface waters were 
quite well-understood to enable the management of catchments and rivers to achieve ecological quality.

Discussion Nevertheless, more work is needed to find out the actual impact of the regulations for single chemicals and complex mixtures, in terms of environmental quality standards to achieve a 'good chemical status', on the good biological status. In a next step after the adoption of the list of PS/PHS substances, which also includes the POPs, the Urban Wastewater Treatment Directive (UWWTD) needs to be adjusted and existing or new treatment options (BATs) should comply with the new requirements of the different directives.

Conclusions Relevant substances threaten human health and the environment by new effects such as CMR, endocrine-disrupting effects or neurotoxicity which are not yet considered in an adequate way by assessment methods and regulatory standards and the application of abatement technologies. The Registration, Evaluation, Authorisation and Restriction of Chemicals helps to control the sources, but WFD, the Stockholm Convention and UWWTD need to be harmonised and a rolling revision process should react on new developments. Finally, to answer the question if the Stockholm Convention and the WFD (2000/60/EC) could reach the target-I would state that they provide a very valuable frame to approach the targets, but there is still way to go to reach them on an EU level and on a global scale, also under the aspects of the Stockholm Convention and the Millennium Development Goals.

Perspectives The compilation of the goals of different regulations and combined actions will save a lot of administrative efforts and money.

Keywords Priority substances and priority hazardous substances (PS/PHS) · POPs · Water regulations ·

Water Framework Directive (WFD) · Technological aspects Stockholm Convention $\cdot$ REACH

\section{Background, aim and scope}

Acceptable water quality is important for different uses, as water is both a vital ecological and economic resource and an essential feature of the natural landscape; but human activity as an important factor in the water cycle can cause great damage to the natural aquatic environment, if we abstract too much or pollute it. The five economic sectors - transport, energy, agriculture, industry and households - contribute most to current problems as many pollution sources are diffuse, numerous and varied and difficult to control. Managing the water cycle in a sustainable way is the key to protect the natural resource and human health. On a global level, the microbiological contamination of water sources is a major problem and the most important issue in connection with poverty.

Our well-being and quality of life - of humans and the environment - depend on the state of the environment and on our ability to ensure the sustainable use of the environment - a task made more complex by the changing nature of human activities that impact it most. On a global level, the microbiological contamination of water sources is a major problem and the most important issue in connection with poverty. On a global level, the most important and ambitious initiative of the United Nations system is the Millennium Development Declaration with the goal of poverty reduction; the lack of functioning excreta management facilities and systems is one of the key contributors to this worldwide disease burden (UNDP 2008). In terms of environmental health, persistent organic pollutants (POPs) circulate globally; as they travel long distances, they are found in remote areas far from their original source of application and can cause damage wherever they move to. Once introduced into the environment, POPs - as their name suggests - are persistent, retain their toxicity and only degrade after decades. Nevertheless, besides the listed 12 substances, we can find different other potentially hazardous chemicals in the environment. In addition, to protect our water resources and the water environment since 2000 the Water Framework Directive (WFD) has been in place as the main European legislation. It requires managing the river basin so that the quality and quantity of water does not affect the ecological services of any specific water body.

The goal of this paper is to discuss whether the Stockholm Convention and the WFD allows meeting the targets of protecting humans and the environment, which are established in the different directives and how we could approach the targets.

\section{Materials and methods}

The aims and scopes of different directives are compiled and compared with the actual quality of water, different approaches of standard settings and potential treatment options are discussed.

\section{Results}

\subsection{Regulative aspects}

In the Stockholm Convention, the UNEP (2008) listed a selection of 12 substances (POPs) - aldrin, chlordane, dichlorodiphenyltrichloroethane, dieldrin, endrin, heptachlor, mirex, toxaphene, polychlorinated biphenyls, dioxins, furans and hexachlorobenzene-and called it the dirty 
dozen. Their subtle long-term toxicity and accumulation in fatty tissue of living organisms is a cause of particular concern since even small quantities can cause nervous system damage, immune system diseases, reproductive or developmental disorders and cancers. Under the Stockholm Convention on POPs, which came into force in May 2004, governments are required to develop a National Implementation Plan (NIP) setting out how they will address their obligations under the convention and how they will take measures to eliminate or reduce the release of POPs into the environment by the use of best available techniques (BAT) and application of best environmental practices (BEP).

In the WFD, the existing European water policy is harmonised by the establishment of a European Union (EU) framework for the protection of inland surface waters, transitional waters, coastal waters and groundwater, in order to prevent and reduce pollution, promote sustainable water use, protect the aquatic environment, improve the status of aquatic ecosystems and mitigate the effects of floods and droughts, based on whole catchments which are viewed as integrated systems. One of its principal objectives is to achieve good chemical and biological water status and to restore rivers, lakes, groundwaters, wetlands and other water bodies to a 'good status' by 2015 (exception 'heavily modified' water bodies). The terms ecological status and chemical status have specific definitions within the WFD. Ecological status is based on biological elements and supported by chemical and physicochemical elements, as well as hydromorphological elements. Chemical status refers to specific pollutants (e.g. priority substances or priority hazardous substances) for which environmental quality standards (EQS) are proposed. The European Commission adopted a proposal for a new directive to protect surface water from pollution on 17 July 2006 (COM
(2006)397 final), which will set limits on concentrations in surface waters of 41 dangerous chemical substances (including 33 priority substances and eight other pollutants) that pose a particular risk to animal and plant life in the aquatic environment and to human health. In addition, EQS will be defined on a national level for certain groups or families of pollutants as minimum requirements. The priority hazardous substances are identified, and the target concentrations are calculated based on the scientific risk assessment procedure laid down in the technical guidance documents (TGD 2003).

The community water policy is based on a combined approach. According to article 10 (WFD 2000/60/EC) for point and diffuse sources, member states shall ensure the establishment and/or implementation of (a) the emission controls based on BAT, or (b) the relevant emission limit values, or (c) in the case of diffuse impacts, the controls including, as appropriate, BEP and of EQS for water, sediment and biota (Fig. 1).

BATs measures could be applied at all levels: production, use or regulatory level including the substitution or outphasing of priority hazardous substances or the limitations of use in certain applications. All significant sources should be considered and the cost-effective and proportionate levels and combination of controls should be identified. The EQS should be complied with by 2015 at the latest and direct discharges of pollutants into surface water should cease by 2025 .

In Europe, the Urban Wastewater Treatment Directive (UWWTD), the Bathing Water Directive, the Nitrates Directive and the Drinking Water Directive (DWD) will also stay in place in addition to the WFD. Due to water scarcity in many areas, the regulation for irrigation water quality will gain more and more importance. Although these directives have different goals, most of them regulate chemical

\section{Biological quality components hydromorphological and general chemical quality}

$\Downarrow$ good ecological status

\section{good status EQS

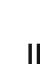

\section{Measures} BAT or BEP}

\section{Priority / priority hazardous substances and "relevant" substances}


and/or microbiological parameters, but do not yet overlap too much in terms of parameters and concentration levels.

The DWD (Council Directive 98/83/EC) regulates a total of 48 microbial and chemical parameters to protect the health of the consumers in the EU and to make sure that the water is wholesome and clean. The parametric values are based on the scientific knowledge available and the precautionary principles (e.g. for pesticides); future parametric values should be based on risk assessment as in the World Health Organisation Guidelines. The Groundwater Directive (2006/118/EC) sets underground water quality standards and introduces measures to prevent or limit inputs of pollutants into groundwater only for chemical parameters in response to the requirements of the WFD. It relates to assessments on chemical status of groundwater and the identification and reversal of significant and sustained upward trends in pollutant concentrations. Although the microbiological contamination is not considered, there is an ongoing discussion about the requirements for wastewater infiltration to sustain the quality for groundwater abstraction for drinking water purposes (Farnleitner et al. 2007). The revised Bathing Water Directive (Directive 2006/7/EC) is based on microbiological indicators of faecal contamination and the list of parameters contains just Escherichia coli and intestinal enterococci. It will apply to surface water where a large number of people are expected to bathe, establishing a method for monitoring bathing water quality during the bathing season. In addition, irrigation water quality requirements (WHO 2006), especially in the case of water recycling, have to consider hygienic and chemical parameters to avoid the contamination of crops and food. WHO (2006) issued health-based targets for treated wastewater use in agriculture and requests for unrestricted irrigation a reduction of 6-7 $\log _{10}$ based on Rotavirus and $3 \log _{10}$ helminth reduction for faecal pollution. The objective of the UWWTD (91/271/EEC) is to protect the environment by prevention of eutrophication or oxygen depletion considering the adverse effects of urban wastewater discharges and discharges from certain industrial sectors. The regulation covers the collection, treatment and discharge of domestic wastewater, mixture of wastewater and wastewater from certain industrial sectors. The Integrated Pollution Prevention and Control (IPPC) Directive (96/61/EEC) is about minimising pollution from various industrial sources; operators of industrial installations covered by Annex I of the IPPC Directive are required to obtain an authorisation (environmental permit) for emissions. In chemical policy, the commission outlined its new strategy for ensuring a high level of chemical safety and a competitive chemicals industry through a system for the registration, evaluation and authorisation of chemicals - the Registration, Evaluation,
Authorisation and Restriction of Chemicals (REACH) system. It entered into force on 1 June 2007. The main aims of REACH are to improve the protection of human health and the environment from the risks that can be posed by dangerous chemicals such as persistent, bioaccumulative and toxic (PBT) or very persistent, very bioaccumulative (vPvB) components, also with hazardous properties; and it makes industry responsible for assessing and managing the risks posed by chemicals and providing appropriate safety information to their users. In parallel, the EU can take additional measures on highly dangerous substances where there is a need for complementing action at the EU level.

\subsection{Status of water in the EU}

Oxygen deficiency is largely under control in many places in the EU and phosphate concentrations in European rivers have been reduced by a third and more-with the biggest reductions in countries which had the largest point source pollution; therefore, eutrophication of lakes and coastal waters has been reduced as a result, but hot spots remain (EEA 2005). The number of monitored lakes with phosphorus concentrations below $25 \mu \mathrm{g} / \mathrm{L}$ has increased from $75 \%$ to $82 \%$ in the past 20 years. According to the EEA (2003), nitrogen pollution, particularly from agriculture, has remained constant and there is no evidence of changes in nitrate levels in the groundwater. Limit values for nitrate in drinking water are exceeded in around one third of groundwater bodies for which information is available. Pollution of rivers by heavy metals and some other heavily regulated chemicals listed in the Dangerous Substances Directive (76/464/EEC) is generally decreasing; but data availability for many other pollutants is too weak to make assessments. However, there is a lack of comparable data on the European scale. This situation will improve as implementation of the WFD (2000/60/EC) progresses (EEA 2005).

Recent international and national studies (BLAC 2003; Bursch et al. 2004; Kim et al. 2007; Metcalfe et al. 2003; Kolpin et al. 2002) indicate that water pollution caused by wastewater effluents persists despite three decades of effort to clean up European surface waters and despite the requirements of the UWWTD and anti-pollution measures. Especially, the organic substances with toxic properties such as pharmaceuticals, biocides, hormones, antibiotics, personal care products, flame retardants and endocrine active substances are increasingly detected in consumer products and the wider environment. They could be found in concentrations in the nanograms per litre to micrograms per litre range, although the lower limits of detection of modern analytical equipment and measured concentrations were generally low, but even low concentration levels can be seen to induce toxic effects (e.g. carcinogenic, mutagenic, toxic to reproduction CMR). The most frequently 
detected compounds in surface and ground water were iodinated X-ray contrast media carbamazepine, diclofenac, bezafibrate fenofibric acid, clofibric acid, triclosan (antimicrobial disinfectant), tri(2-chloroethyl)phosphate (flame retardant) and 4-nonylphenol (nonionic detergent metabolite). Mainly in the Mediterranean countries, concentrations of nonylphenol still exceed the predicted no-effect concentration of $0.33 \mu \mathrm{g} / \mathrm{L}$ and they are still present in the aquatic environment (Bursch et al. 2004). The detection of multiple contaminations was common, but little is known about the potential interactive effects such as synergistic or antagonistic toxicity that may occur from complex mixtures or from metabolites (Kolpin et al. 2002).

It is estimated that $70 \%$ of worldwide water use is for irrigation. In this case, faecal pollution of waters is crucial. Agriculture is a significant user of water resources in Europe, accounting to around $30 \%$ of total water use. In southern Europe (where it is a fundamental input), irrigation accounts for over $60 \%$ of water use in most countries; in northern member states, it ranges from $0 \%$ to over $30 \%$. However, in arid and semiarid areas, wastewater is considered as a valuable resource and is being increasingly used for irrigation of agricultural crops in both developing and industrialised countries.

\subsection{Wastewater quality}

The major sources of contamination of freshwater systems are derived from wastewater emissions. Untreated wastewater generally contains high levels of organic material, numerous pathogenic microorganisms, as well as nutrients, salts, suspended solids, acids and bases, metals and toxic organic compounds which could cause specific problems. The microbiological contamination for raw wastewater is well-known and the WHO (2006) lists numbers of index organisms per $100 \mathrm{~mL}$ for $E$. coli $10^{6}-10^{8}$, for faecal streptococci/intestinal enterococci $4.7 \times 10^{3}-4 \times 10^{5}$ and for polioviruses $180-500,000$ and $1-1,000$ helminths. In comparison to microbiological contamination, the type and concentrations of potentially hazardous substances can be very varying; as many compounds are registered and new are developed. Emerging contaminants are chemicals or materials of interest that are characterised by a potential or real threat to human health or the environment; the list of 'emerging contaminants' includes personal care, medical, industrial and household products such as drugs, biocides, fragrances, pesticides, plasticisers, detergents and metabolites, antioxidants, combustion indicators and flame retardants - this list is not comprehensive and is changing frequently. Many of these chemical compounds, or types of compounds, have been found to be globally ubiquitous and persistent.

Nevertheless, the mere detection of contaminants in water does not mean that there is a risk connected to that, but this question can only be answered with the help of a risk assessment which requires comprehensive knowledge; but if this knowledge is not available at a proper time, no action is taken. This often results in a respectable loss of time; therefore, it is often necessary to react on existing problems, which have already caused considerable harm. It requires prevention and control at source. On time scale, the precautionary principle which is often applied in regulations acts in advance of potential damage, whereas risk assessment is often lacking behind. Measures based on the precautionary principle shall be re-examined regularly and, if necessary, modified depending on the results of the scientific research and the follow-up of their impact (EU 2002).

\subsection{Wastewater treatment}

Conventional biological municipal wastewater treatment plants (WWTPs) are designed to remove or to decrease the loads of bulk organic and inorganic constituents that may pollute the receiving waters and lead to oxygen depletion and eutrophication; as a side effect, the concentrations of pathogens are also reduced ranging from $0-1 \log _{10}$ removal for sedimentation to $1-2 \log _{10}$ for a removal of secondary treatment (WHO 2006). Usually, the design of a WWTP does not focus on the removal of trace organic pollutants, which depend on the persistence of the individual compound, its sorption behaviour, its volatility and the technology and operation conditions (e.g. temperature, redox potential, sludge retention time [SRT]) applied. Ternes (1998) found 32 drug residues as well as five metabolites in German WWTP discharges, river and stream waters, which were detectable in at least one municipal WWTP effluent with concentration levels up to $6.3 \mu \mathrm{g} / \mathrm{L}$ (carbamazepine). Removal rates showed a great variability according to sewage treatment plants and types of treatments (e.g. biological, physicochemical) with better removal rates at high SRT (Clara et al. 2005).

Membrane treatment (MBR) removed microbiological indicators with $5 \log$ removal of $E$. coli more efficiently than did the tertiary filtration and upflow anaerobic sludge blanket line (Ottoson et al. 2006). WHO (2006) considers membranes removing viruses and bacteria from 2.5 to $>6$ $\log _{10}$. MBR is a promising technology able to achieve efficient removal of micropollutants, due to long SRT and low sludge loads (Joss et al. 2005). Fürhacker et al. (2006) showed that CMR substances, such as cytostatic compounds such as 5-fluorouracil and anthracyclines, could be removed in an MBR below limit of detection. Kim et al. (2007) applied reverse osmosis and nanofiltration showing excellent removal (>95\%) for all target analytes.

Oxidation processes and disinfection with $\mathrm{Cl}_{2}$ or ozone give excellent results in $\log$ unit reduction of up to $6 \log _{10}$ or inactivation of excreted pathogens (WHO 2006). 
Advanced oxidation processes applying ozone $\left(\mathrm{O}_{3}\right), \mathrm{O}_{3} / \mathrm{UV}$ or $\mathrm{H}_{2} \mathrm{O}_{2} / \mathrm{UV}$ are recently also used for the removal of trace pollutants, e.g. pharmaceuticals, and for promoting water recycling and reuse (Vogna et al. 2004; Huber et al. 2005). Nonetheless, reaction pathways, reactor design, application in wastewater mixture and objectionable daughter products still need to be investigated.

\section{Conclusions and perspectives}

New and existing substances threaten human health and the environment by new forms of invisible and time-delayed effects such as carcinogenic, mutagenic, toxic to reproduction (CMR), endocrine-disrupting effects or neurotoxicity which are not yet considered in an adequate way through assessment methods and regulatory standards and the application of abatement technologies. One appropriate tool is REACH, which helps to control the sources. Nevertheless, to meet the goals of recreational, bathing water and drinking water use, but also that of WFD and the Stockholm Convention-REACH, WFD and UWWTDneed to be harmonised and a continuous flexible revision process should react on new developments after appropriate assessment of the hazard or the risk and BAT need to be developed for the application in the UWWTD. Finally, to answer the question if the Stockholm Convention and the WFD (2000/60/EC) could reach the target, I would state that they provide a very valuable frame to approach the targets, but there is still way to go to reach them on an EU level and on a global scale, also under the aspects of the Stockholm Convention and the Millennium Development Goals.

\section{References}

BLAC (2003) Bund/Länderausschuss für Chemikaliensicherheit (BLAC). Arzneimittel in der Umwelt. Auswertung der Untersuchungsergebnisse Arznei03 aktuell Bearbeitungsstand: 19.03.2004 16:54. Bericht an die 61. Umweltministerkonferenz (UMK) am 19./20. November 2003 in Hamburg. Publikationsfreigabe durch die 32. Amtschefkonferenz (ACK) am 6. November 2003 in Berlin

Bursch W, Fürhacker M, Gemeiner M, Grillitsch B, Jungbauer A, Kreuzinger N, Möstl E, Scharf S, Schmid E, Skutan S, Walter I (2004) Endocrine disrupters in the aquatic environment: the Austrian approach-ARCEM. Water Sci Technol 5(50):293-300

Clara M, Strenn B et al (2005) Removal of selected pharmaceuticals, fragrances and endocrine disrupting compounds in a membrane bioreactor and conventional wastewater treatment plants. Water Res 39(19):4797-4807

EEA (2003) EEA briefing status of Europe's water, no. 1/2003

EEA (2005) Effectiveness of urban wastewater treatment policies in selected countries - an EEA pilot study. Copenhagen European Environment Agency, EEA 2, Copenhagen

EU (2000) Commission of the European Communities, communication from the commission on the precautionary principle, vol 1 . Brussels

Farnleitner A, Mach RL, Reischer GH, Kavka GG (2007) Mikrobiologische-hygienische Risiken trotz Abwasserentsorgung nach dem Stand der Technik? Wiener Mitteilungen Bd 201

Fürhacker M, Lenz K, Mahnik S, Weissenbacher N, Mader R, Knasmüller S, Ferk F, Uhl M, Bursch W, Köllensperger G, Hann S (2006) Chemische Analyse, Risikobewertung und Entfernung von ausgewählten Zytostatika aus Abwasserströmen aus Krankenhäusern, Teil II-Risikoabschätung und Risikomanagement. BMLFUW, 168

Huber MM, Gobel A, Joss A, Hermann N, Loffler D, McArdell CS, Ried A, Siegrist H, Ternes TA, von Gunten U (2005) Oxidation of pharmaceuticals during ozonation of municipal wastewater effluents - a pilot study. Environ Sci Technol 39(11):4290-4299

Joss A, Keller E et al (2005) Removal of pharmaceuticals and fragrances in biological wastewater treatment. Water Res 39 (14):3139-3152

Kim SD, Cho J et al (2007) Occurrence and removal of pharmaceuticals and endocrine disruptors in South Korean surface, drinking, and waste waters. Water Res 41(5):1013-1021

Kolpin ET, Furlong MT, Meyer EM, Thurman SD, Zaugg LB, Barber LB, Buxton HT (2002) Pharmaceuticals, hormones, and other organic wastewater contaminants in U.S. streams, 1999-2000 - a national reconnaissance. Environ Sci Technol 36(2002):1202-1211

Metcalfe CD, Xiu-Sheng M, Koenig Brenda G, Struger J (2003) Distribution of acidic and neutral drugs in surface waters near sewage treatment plants in the lower Great Lakes, Canada. Environ Toxicol Chem 22:2881-2889

Ottoson J, Hansen A, Björlenius B, Norder H, Stenström TA (2006) Removal of viruses, parasitic protozoa and microbial indicators in conventional and membrane processes in a wastewater pilot plant. Water Res 40(7):1449-1457

Ternes TA (1998) Occurrence of drugs in German sewage treatment plants and rivers. Water Res 32(11):3245-3260

TGD (2003) Technical guidance document (TGD) on risk assessment in support of Commission Directive 93/67/EEC on risk assessment for new notified substances, Commission Regulation (EC) no 1488/94 on risk assessment for existing substances, Directive 98/8/ EC of the European Parliament and of the Council concerning the placing of biocidal products on the market. Available at http://ecb. jrc.it/cgi-bin/reframer.pl?A=ECB\&B=/tgdoc/

UNDP (2008) United Nations Development Programme Millennium Development Goals (MDGs). http://www.undp.org/mdg/

UNEP (2008) Stockholm Convention. Available at http://chm.pops.int/

Vogna D, Marotta R et al (2004) Advanced oxidation of the pharmaceutical drug diclofenac with UV/H2O2 and ozone. Water Res 38(2):414-422

WHO (2006) Guidelines for the safe use of wastewater, excreta and greywater. Vol 2-wastewater use in agriculture. World Health Organization, ISBN 9241546867 